\title{
ФОРМИ, МЕТОДИ ТА ЗАСОБИ НАВЧАННЯ І ВИХОВАННЯ У МОРСЬКИХ ЗАКДАДАХ ОСВІТИ ПІВДНЯ УКРАЇНИ У 60-ТІ РОКИ ХХ СТОДІТТЯ
}

У статті висвітлено основні форми, методи та засоби навчання і виховання у морських закладах освіти півдня України у 60-ті роки ХХ століття. У дослідженні використовувалися архівні матеріали Одеського морехідного училищца Мінтрансбуду СРСР. Проаналізовано навчальну, методичну, виховну та наукову роботу, діяльність цциклових комісій, бібліотеки. Виявлено, що впродовж визначеного періоду постійно проводився пошук нових форм, методів та засобів навчання та виховання. Наприклад, здійснено експеримент з програмованого контролю знань за допомогою машин та перфокарт. Широкого розповсюдження набули кіноуроки, що підвищило інтерес курсантів до предметів та позитивно відбилося на їхній успішності. Впроваджувалися нові форми організациї навчання, такі як: семінари, класні технічні конференції, взаємоопитування курсантів, реферати. 3 метою підвищення якості освітнього процесу застосовувалися різноманітні технічні засоби навчання, серед яких активне впровадження отримали діафільми. Наведено приклади тем проведених відкритих уроків. Розглянуто роботу бібліотеки, зокрема заходи з метою популяризації книги. Визначено, щз завданняли виховання були: формування комуністичного світогляду; виховання радянського патріотизму та пролетарського інтернаціоналізму; виховання комуністичної моралі; естетичне виховання; організація та виховання згуртованого колективу задля зміццнення ідейної переконаності курсантів, підвищення їхньої політичної грамотності; сприянню вихованню патріотичних почуттів, любові до Радянської Батьківщини та Комуністичної партії. Центтральними темами у навчанні та вихованні курсантів були життл та політична діяльність В.І. Аеніна, а також подї, пов'язані з Великою Жовтневою соціалістичною революиією.

Ключові слова: форми, методи, засоби навчання і виховання, морська освіта, курсанти.

Постановка проблеми. Морська освіта України перебуває на етапі поліпшення існуючої системи підготовки морських спеціалістів і пошуку нових методів, форм, засобів навчання та виховання, оскільки країна потребуе висококваліфікованих фахівців цієї галузі. Для того, щоб знайти оптимальні шляхи покращення якості освіти, необхідно проаналізувати досвід минулого в цьому питанні, аби обрати найкраще та виправити помилки.

Аналіз досліджень. Аналізу розвитку морської освіти приділяеться багато уваги, iii розглядали в різних аспектах такі вчені, як В.С. Зодотовська, А. В. Ліпшиць, А. І. Аяшкевич, І. М. Рябуха, А. М. Скриннік, А. О. Солодовник, О. Я. Тимофєева.

Мета статті - висвітлити основні форми, методи та засоби навчання і виховання у морських закладах освіти півдня України у 60-ті роки XX століття.

Виклад основного матеріалу. В основу навчально-виховної роботи досліджуваного періоду було покладено Постанову ЦК КПРС та Ради Міністрів СРСР від 3 вересня 1966 р. № 729 «Про заходи 3 поліпшення підготовки фахівців і вдосконалення керівництва вищою і середньою спеціальною освітою в країні» [1],

*C) Овчиннікова О. М.

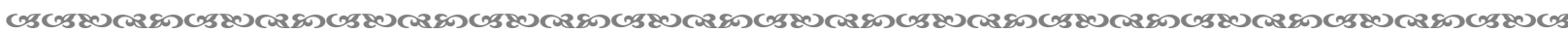
271 
а також заходи по підготовці святкування 50-ї річниці Великої Жовтневої соціалістичної реводюції та дня народження Леніна.

Методична робота проводилася з таких питань:

1) вивчення та використання нових методів викладання;

2) загальної педагогіки;

3) методи вдосконалення в урочній роботі;

4) методи вдосконалення майстерності викладачів;

5) покращення успішності курсантів.

Особливу увагу приділено здійсненню експерименту 3 програмованого контролю знань за допомогою машин та перфокарт, розширенню міжпредметних зв'язків. Було доведено, що програмованого контродю недостатньо, щоб оцінити знання курсантів, тому поряд 3 ним необхідно проводити контродь звичайними засобами. Разом 3 тим, там, де проводився програмований контроль, підвищилась успішність. Головною причиною цього є краща підготовка курсантів до уроків, тому що вони знають, що їх неминуче проконтродюють.

Написані такі методичні розробки:

1) «Наша країна» (англійською мовою з елементами програмування);

2) «Дондон» ( англійською мовою);

3) «По використанню технічних засобів на заняттях з англійської мови»;

4) «Програмований контроль знань за допомогою перфокарт на заняттях 3 англійської мови»;

5) «Доменна піч» (англійською мовою).

6) «Методика проведення уроку-конференції 3 теми «Дітература Великої Вітчизняної війни»;

7) «Алгоритмізація у навчанні російської мови»;

8) «Методика викладання суспільних дисциплін»;

9) «Методика викладання теми «Сім'я моряка»; мовою)

10) «Методика викладання теми «Місто та засоби пересування» (англійською

11) «Методика викладання теми «Плавальна практика» англійською мовою);

12) «Біографія та огляд творчості Ф. М. Достоєвського»;

13) «Злочин та покарання» - роман духовних пошуків»;

14) «Радянський Союз - оплот миру та демократії (англійською мовою) тощо [5].

Циклові комісії проводили засідання, на яких були розглянуті такі теми доповідей: мови;

1) методичні рекомендації про єдиний режим грамотного письма та кудьтури

2) вивчення праць Леніна на уроках історії та суспільствознавства;

3) про деякі психологічні особливості самостійної роботи курсантів;

4) організація самостійної роботи курсантів;

5) пропозиції про підвищення продуктивності уроків;

6) аналітичні читання та переклад іноземних текстів;

7) форми самостійної роботи на уроках та прищеплення навичок самостійної роботи у позаурочний час;

8) Ушинський про мову та думки про вивчення іноземних мов;

9) огляд праць А. Макаренка про виховання мододі та інші [5].

До 100-річчя 3 дня народження Деніна циклові комісії провели олімпіади, вечори цікавої науки, написані реферати, заслухані доповіді. Наприклад, циклова комісія англійської мови провела такі заходи: була заслухана доповідь «В. І. Ленін про комуністичне виховання», виготовлено діафільм «Денін», проведено урок із ленінської 
тематики. Циклова комісія суспільних дисциплін та літератури провела такі заходи: виготовлено електрифікований стенд «Тут жив і працював Ленін», електрифіковану мапу «По ленінському шляху».

У 60-ті роки XX століття використовувалися такі форми уроків:

- кіноурок;

- комбінований урок;

- урок-лекція;

- урок-семінар;

- програмований урок;

- урок-повторення;

- урок у музеї;

- урок на виробництві;

- практичне заняття;

- самостійна робота на уроці;

- урок-співбесіда;

- урок із контролем знань за допомогою перфокарт;

- урок із програмованим машинним опитуванням;

- урок 3 широким використанням технічних засобів (магнітофони, ларингофони, діапроєктори, кіноапарати та інші) [3; 4].

Широкого розповсюдження набули кінокуроки. Велику кількість їх проведено з таких дисциплін, як історія СРСР, суспільствознавство, англійська мова, російська література. Застосування кіноуроків підвищило інтерес курсантів до предметів та позитивно відбилося на успішності, дало можливість курсантам більш глибоко осмислити матеріал, що вивчався, побачити роботу механізмів, установок та виконання робіт у дії, ознайомитися з останніми досягненнями науки та техніки. У резудьтаті значно підвищилися знання та успішність. Демонстрація навчальних та наукових кінофільмів проводилася у спеціальних демонстраційних приміщеннях або безпосередньо у кабінетах, обладнаних кіноустановками.

Впроваджувалися нові форми організації навчального процесу, такі як: семінари, класні технічні конференції, взаємоопитування курсантів, реферати. Застосовувадися деякі форми програмованого навчання, переважно опитування за допомогою перфокарт.

Широко практикувалося проведення занять у кабінеті програмованого навчання, у кабінеті англійської мови, обладнаному засобами звукозапису, велика кількість занять проводилось із демонстрацією діафільмів за допомогою діапроєкторів «ДЭТИ» [3-7].

3 метою підвищення якості освітнього процесу застосовувалися технічні засоби навчання:

1) діафільми;

2) навчальні машини, розповсюдження отримало програмоване опитування за допомогою перфокарт;

3) магнітофон - при проведенні занять з англійської мови, російської дітератури, суспільствознавства часто застосовувався магнітофон, що давало мождивість здійснювати запис та прослуховувати тексти, покращувати вимову курсантів на заняттях 3 ангдійської мови;

4) заняття на виробництві.

Було виготовлено наступні діафільми:

1) Судові котди (ангдійською мовою);

2) На нашому англійському занятті;

3) Наш робочій день (ангдійською мовою); 
4) Розвиток днопогдиблювального фдоту (ангдійською мовою);

5) Наше учидище (англійською мовою);

6) Покупка (ангдійською мовою);

7) Розвиток днопоглиблювального флоту (ангдійською мовою);

8) Двигуни внутрішнього згорання (ангдійською мовою);

9) Парові та газові турбіни (англійською мовою)

10) Пори року (англійською мовою);

11) Життя та творчий шлях I. С. Тургенєва;

12) Їжа (ангдійською мовою);

13) В. І. Денін (англійською мовою) [3-7].

Були проведені відкриті заняття за такими темами:

1) 3 англійської мови «Частини судна»;

2) 3 англійської мови «Наша країна»;

3) 3 англійської мови «Мій робочий день»;

4) 3 англійської мови «У братській сім'ї народів СРСР»;

5) 3 ангдійської мови «Нью-Йорк»;

6) 3 історії «Англія у кінці XIX - початку XX століття»;

7) 3 російської дітератури «Дітература $50-x$ років»;

8) 3 суспільствознавства «Розвиток соціалістичної державності у комуністичне суспільне самоврядування» [3-7].

Проводилася масова робота та наочна пропаганда книги, яка вкдючала:

1) книжково-ілюстративно виставки, такі як: «140 років 3 дня повстання декабристів», «Досягнення радянської космонавтики», «Найдемократичніша Конституція у світі», «150 років 3 дня народження К. Маркса», «Вони захищали Батьківщину» та інші;

2) читацькі конференції «Мододі поети-сучасники», «Буревісник революції», «Вони боролися за владу рад»;

3) диспут з теми «Культура дюдських відносин»;

4) вечір поезіі;

5) виставка картин Сурікова;

6) тематичні вечори «У людині повинно бути все прекрасним», «До 50-річчя Денінського комсомолу» та інші;

7) плакати та стенди: «До 100-річчя 3 дня народження А. М. Горького», «3 днем народження, Батьківщина моя», «Денін в образотворчому мистецтві»;

8) бесіди у питаннях та відповідях «Біля мапи світу» тощо.

Працювали предметні та технічні гуртки:

- суспільствознавства;

- літературний;

- історичний;

- англійської мови.

Предметні та технічні гуртки займалися організацією екскурсій до музею, за маршрутами революційних подій; відвідування виставок, планетарію; випуску стінних газет; підготовки доповідей та рефератів; написання сценаріїв та виготовлення діафільмів; підготовки до проведення тематичних вечорів та тематичних конференцій тощо.

Гурток ангдійської мови випускав стінну газету ангдійською мовою, де буди висвітлені останні новини в країні та за кордоном. Гуртки російської дітератури, суспільствознавства та англійської мови провели декілька тематичних вечорів: «Цих днів не змовкне слава» «Буревісник революції» (до 100-річчя А. М. Горького) та ін. 
При кабінеті суспільствознавства на тлі мапи світу учасниками предметного гуртка було обладнано куток «Світ сьогодні», який регулярно поповнювався останньою інформацією про найваждивіші політичні події у країні та за кордоном.

На ознаменування 50-ої річниці Великої Жовтневої соціалістичної революції курсанти взяли на себе підвищенні зобов'язання з успішності в навчанні. Списки таких курсантів були виділені у кожному класному журналі та вивішені в навчальному корпусі та в екіпажі.

Робота бібліотеки визначалась наступними завданнями:

1) пропаганда літератури до 50-ої річниці Великої Жовтневої соціалістичної революції;

2) пропаганда творів В. І. Леніна та дітератури про його життя та діяльність;

3) забезпечення навчальною літературою освітнього процесу;

4) пропаганда економічних знань;

5) естетичне виховання курсантів.

Комплектування бібліотеки включало:

1) підготовлено тематичні картки: «До 50-річчя Денінського комсомолу», «В.І. Денін - великий друг та вчитель молоді», «Історія Денінського комсомоду», «50 років Радянських Збройних сил», «Поеми, вірші та пісні про комсомол», «50 років КП України»;

2) зроблені бібліографічні огляди літератури: «Художники слова про В. І. Леніна», «Нові книги про В.І. Деніна», «Сторінки ведикого подвигу (дітература про Ведику Вітчизняну війну)»;

3) складено рекомендаційні вказівники літератури.

Робота бібліотеки проводилася під знаком підготовки до святкування 100-річчя 3 дня народження В.І.Леніна. Були складені рекомендаційні вказівники літератури, тематичні картотеки для вивчення спадщини Деніна, його життя та діядьності («Денінізм - прапор нашої епохи, «Говорять соратники Іиьїча»).

Бібліотека провела читацьку конференцію на тему: «Образ Деніна у художній прозі», тематичні вечори: «Із Деніним у серці», бесіди: «Денінський комсомод активний помічник партії», «Бережи книгу - джерело знань», відкриті перегдяди літератури: «Сторінки великого життя» (книги про Деніна), «Воєнно-мемуарна література».

Зроблені бібліографічні огляди літератури: «Нові книги про життя та діяльність B. І. Деніна», «Про комуністичне виховання молоді», «Економічне суперництво двох систем» тощо [2-7].

Ідейно-політичне виховання було спрямовано на втілення у життя постанови ЦК КПРС від 4 січня 1967 року «Про підготовку до 50-ліття Великої Жовтневої Соціалістичної революції». Ідейно-політичне виховання проводилося у різних формамах навчальної роботи в класах, а також у позакласний час. Одним із найваждивіших засобів формування наукового світогляду було вивчення суспільнополітичних предметів згідно навчального плану - історії, суспільствознавства, економіки, літератури. Курсанти залучалися до поглибленого вивчення в індивідуальному порядку окремих етапів історії Комуністичної партії та Радянської Батьківщини із наступним написанням рефератів 3 цих питань.

Форми політико-виховної та культурно-масової роботи постійно вдосконалювадися, завдяки чому досягалися більш високі результати в навчанні, зміцнювалася дисципліна, виховувалися ідейно загартовані та висококваліфіковані спеціадісти для народного господарства.

Завданнями ідейно-політичної та культурно-масової роботи були:

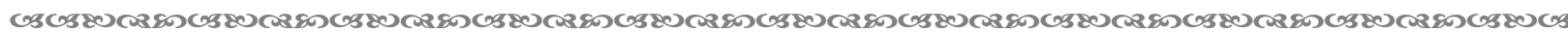
275 
1) формування комуністичного світогляду;

2) виховання радянського патріотизму та пролетарського інтернаціоналізму;

3) виховання комуністичної моралі, естетичне виховання;

4) організація та виховання згуртованого колективу.

Трудове виховання курсантів здійснювалося на виробництві, у навчальних майстернях, у повному самообслуговуванні у гуртожитку та в аудиторіях навчального корпусу, на польових роботах у колгоспах та радгоспах.

Велику лекційну пропагандистську роботу проводила лекторська група, яка була об'єднана у товариство «Знання», виступаючи 3 доповідями на загальнополітичні, воєнно-патріотичні, морально-етичні, атеїстичні теми. У зв'язку із підготовкою до 50-річчя Великого Жовтня були прочитані лекції із циклу «Жовтневі читання», «Денінські читання». Оновлювалася наочна агітація, наприклад, стенди, присвячені комсомолу, захисникам Вітчизни та інші.

Однією із форм ідейно-політичного виховання були політгодини, які проводидися класними керівниками. У ці ж години проходиди виховні заходи: бесіди, співбесіди, диспути, зустрічі. Бесіди проводилися на такі теми, як: про морадьну та духовну поведінку, про дбайливе поводження з морською формою, про дружбу та товариство, про ставлення до жінки, про любов та дружбу тощо.

Складовою частиною подітико-виховної та кудьтурно-масової роботи є художня самодіяльність. Були створені колективи художньої самодіяльності: духовий оркестр, оркестр електромузики, танцювальний колектив, вокальний та хоровий. Постійно проводилися вечори відпочинку, КВК, демонстрація художніх кінофільмів, таких як: «Тихий Дон», «Иван Бровкин на целине», «Судьба человека», «Овод», «Здесь жил Яенин», «Именем Чайковского», «Полёт в космос» та інші, зустрічі із артистами театрів та кіно тощо. Проводилися тематичні вечори: «Естафета поколінь» (зустрічі із комсомодьцями 20-х років), «Я громадянин Радянського Союзу» (до дня Конституції СРСР), «Цих років не змовкне слава» (вечір, присвячений героям громадянської війни), «Дорогами батьків - дорогами героїв» (зустріч із учасниками Великої Вітчизняної війни), «Розкинулось море широко» (конкурс на найкраще виконання танцю, пісні, вірша, оповідання про море).

Виховна робота проводилася також і в позаробочий час у гуртожитку. У кожній роті були створені Денінські кімнати, через які проводилися основні політико-виховні заходи. Велику увагу приділяли наочній агітації, газетам-стіннівкам, де викривали порушників дисципліни, курсантів, які відстають у навчанні.

Із випускниками проводидися індивідуальні співбесіди, на яких перевірялися політична зрілість, організаційні якості, їх роль на виробництві як організаторів та вихователів колективу. Результати співбесіди записувалися у характеристику, яка надсилалася за місцем призначення на роботу.

Форми політичного виховання зміцнювали ідейну переконаність курсантів, підвищували їхню політичну грамотність, сприяли вихованню патріотичних почуттів, любові до Радянської Батьківщини та Комуністичної партії [2-7].

Висновки. Отже, проведений аналіз наказів та постанов СРСР, архівних даних дозводив з'ясувати, які основні форми, методи та засоби навчання та виховання використовувадися у морських закладах освіти півдня України у 60-ті роки XX століття. Встановлено, що форми, методи та засоби навчання i виховання постійно вдосконалювадися, відбувалися оптимізація існуючого та пошук нового задля підвищення успішності навчання курсантів та зміцнення їхньої дисципліни. 
Перспективи подальших досліджень вбачаємо в розгляді форм, методів та засобів навчання та виховання у морських закладах освіти півдня України на інших історичних етапах розвитку підготовки фахівців морської галузі.

\section{Список використаних джерел:}

1. О мерах по улучшению подготовки специалистов и совершенствованию руководства высшим и средним специальным образованием в стране. URL: http://www.libussr.ru/ doc ussr/usr 6463.htm

2. Отчёт о работе Одесского мореходного училища Минтрансстроя СССР за 1958-1959 учебный год. Державний архів Одеської області. (ДАОО).Ф. Р.7953. Оп. 1. Спр. 61. Арк. 1-98.

3. Отчёт о работе Одесского мореходного училища Минтрансстроя СССР за 1965-1966 учебный год. ДАОО. Ф. Р. 7953. Оп. 1. Спр. 94. Арк. 1-71.

4. Отчёт о работе Одесского мореходного училища Минтрансстроя СССР за 1966-1967 учебный год. ДАОО.Ф. Р. 7953. Оп. 1. Спр. 107. Арк. 1-168.

5. Отчёт о работе Одесского мореходного училища Минтрансстроя СССР за 1967-1968 учебный год. ДАОО. Ф. Р. 7953. Оп. 1. Спр. 119. Арк. 1-148.

6. Отчёт о работеОдесскогомореходного училища Минтрансстроя СССР за 1968-1969 учебный год.ДАОО. Ф. Р. 7953. Оп. 1. Спр. 133. Арк. 1-137.

7. Отчёт о работе Одесского мореходного учидища Минтрансстроя СССР за 1969-1970 учебный год. ДАОО. Ф. Р. 7953. Оп. 1. Спр. 145. Арк. 1-189.

\section{References:}

1. O merah po uluchsheniyu podgotovki spetsialistov i sovershenstvovaniyu rukovodstva vyisshim i srednim spetsialnyim obrazovaniem $\mathrm{v}$ strane [On measures to improve the training of specialists and improve the management of higher and secondary specialized education in the country]. Retrieved from http://www.libussr.ru/doc ussr/usr 6463.htm [in Russian].

2. Otchyot o rabote Odesskogo morehodnogo uchilischa Mintransstroya SSSR za 19581959 uchebnyiy god [Report of the work of the Odessa Navigation College of the Ministry of Transport of the USSR (1958-1959)] (Fund 7953. Inventory 1. File 61. Leaves 1-98). State Archive of Odesa Region, Odesa [in Russian].

3. Otchyot o rabote Odesskogo morehodnogo uchilischa Mintransstroya SSSR za 19651966 uchebnyiy god [Report of the work of the Odessa Navigation College of the Ministry of Transport of the USSR (1965-1966)] (Fund 7953. Inventory 1. File 94. Leaves 1-71). State Archive of Odesa Region, Odesa [in Russian].

4. Otchyot o rabote Odesskogo morehodnogo uchilischa Mintransstroya SSSR za 19661967 uchebnyiy god [Report of the work of the Odessa Navigation College of the Ministry of Transport of the USSR (1966-1967)] (Fund 7953. Inventory 1. File 107. Leaves 1-168). State Archive of Odesa Region, Odesa [in Russian].

5. Otchyot o rabote Odesskogo morehodnogo uchilischa Mintransstroya SSSR za 19671968 uchebnyiy god [Report of the work of the Odessa Navigation College of the Ministry of Transport of the USSR (1967-1968)] (Fund 7953. Inventory 1. File 119. Leaves 1-148). State Archive of Odesa Region, Odesa [in Russian].

6. Otchyot o rabote Odesskogo morehodnogo uchilischa Mintransstroya SSSR za 19681969 uchebnyiy god [Report of the work of the Odessa Navigation College of the Ministry of Transport of the USSR (1968-1969)] (Fund 7953. Inventory 1. File 133. Leaves 1-137). State Archive of Odesa Region, Odesa [in Russian].

7. Otchyot o rabote Odesskogo morehodnogo uchilischa Mintransstroya SSSR za 19691970 uchebnyiy god [Report of the work of the Odessa Navigation College of the Ministry of Transport of the USSR (1969-1970)] (Fund 7953. Inventory 1 File 145. Leaves 1-189). State Archive of Odesa Region, Odesa [in Russian]. 


\section{FORMS, METHODS AND TEACHING RESOURCES OF EDUCATION AND TRAINING IN MARITIME EDUCATIONAL ESTABLISHMENTS OF SOUTHERN UKRAINE IN THE 60'S OF THE XX CENTURY}

The article specifies the main forms, methods and teaching resources of education and training in Ukraine in the 60s of the twentieth century.The archival data of Odessa Navigation College of the Ministry of Transport of the USSR were used as an example. The educational, methodical, training and scientific work, its cycle commissions, the work of library were analyzed. During a certain period, these arch of new forms, methods and teaching resources of education and training was constantly carried out. For example, an experimental lessons with using of screen became wide spread, which increased a positive effect on their progress in knowledge.New forms of educational process were introduced, such as seminars, class technical conferences, cadets'back-to-back interrogation, reference papers. In order to improve the quality of the educational process, various teaching resources were used .Examples of open lessons topics are given. The work of the library is considered, in particular measures to promote the book.It is determined that the tasks of training were: the formation of a communist worldview; training of Soviet patriotism and proletarian internationalism; training of communist morality, aesthetic training; organization and training of a consolidated team to strengthen the ideological conviction of cadets, increase their political literacy, promote the training of patriotic feelings, love for the Soviet Motherlandand the CommunistParty. The central figure in the educationanl training of cadets was occupied by Lenin, his life and political activities, as well as event s related to the Great Octobe rSocialist Revolution.

Key words: forms, methods, means of teaching resources of education and training, maritime education, cadets.

\section{ОРГАНІЗАЦІЙНО-МЕТОДИЧНА РОБОТА КАМ'ЯНЕЦЬ-ПОДІЛЬСЬКОГО (З 1954 Р. ХМЕЛЬНИЦЬКОГО) ОБЛАСНОГО ІНСТИТУТУ ВДОСКОНАЯЕННЯ ВЧИТЕЛІВ У ДРУГІЙ ПОЛОВИНІ 40-Х РР. ХХ СТ.}

На підставі аналізу архівних документів розкриваються основні напрями організаційнометодичної роботи Інституту із закладами й установами освіти в другій половині 40-х рр. $X X \mathrm{~cm}$.

За результатали проведеного дослідження нами встановлено, що організаційнометодична робота Інституту була спрямована на проведення навчання (курсів підвищення кваліфікації), семінарів, консультацій, розробку методичних рекомендацій щзодо навчальновиховного процесу, організаційно-методичний супровід роботи педагогічних кабінетів методичних об'єднань учителів, узагальнення й опис педагогічного досвіду і таке інше.

*C) Соловей M. B.

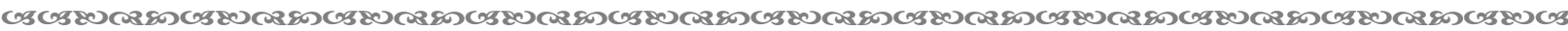
278 